\title{
ПСЕВДОНІМИ В АНТРОПОНІМІЙНІЙ СИСТЕМІ УКРАЇНСЬКОЇ МОВИ
}

\section{Павликівська Н. М., Прокопчук Л. В.}

\section{ВСТУП}

Важливе місце в антропонімійній системі національної мови посідають псевдоніми як різновид власних найменувань людей. Зміст поняття «псевдонім» сформувався ще в античному світі. Алотріоніми (алоніми) використовувано у Візантії. Відомими й досить популярними стали псевдоніми в епоху Відродження, особливо, коли поширилося друковане слово. Дуже багато їх було в другій половині XVIII століття у Франції. В Україні псевдоніми з'явилися в XVI столітті, а використання їх помітно пожвавилося у XVII столітті в період визвольних рухів українського народу.

Екстралінгвальні (соціальні, психологічні) чинники псевдонімності в культурному письменницькому середовищі та в середовищі учасників нелегальної політичної боротьби, незаконної, злочинної, прихованої діяльності різні. Так, відомо, що складні суспільно-політичні умови XIX - поч. XX ст. змушували письменників, журналістів, критиків та інших діячів культури приховувати свої справжні імена та прізвища за псевдонімами. Переслідування набуло такого розмаху, що вони користувалися псевдонімами і в усному спілкуванні та в листах. Крім того, появу псевдонімів у колах творчої інтелігенції зумовлювали: авторська скромність, традиції, немелодійність справжнього прізвища, невпевненість у авторських силах, службове становище, що не дозволяло публічно виступати під власним прізвищем, плагіат. В історії української культури трапляються псевдоніми, зумовлені лише модою на них. Здебільшого про моду на псевдоніми в Україні можна говорити щодо останньої чверті XIX і перших десятиріч XX ст. У середині - наприкінці XX ст. багато письменників використали псевдоніми для того, щоб виразити свою творчу індивідуальність, друкуватися в різних виданнях. Більшість літературних псевдонімів мали не громадське, а лише особисте підгрунтя. Нині новітні літературні псевдоніми XXI століття слугують для самоідентифікації та позиціонування автора в суспільстві.

Псевдонімія в Україні особливо поширилася у зв'язку із суспільнополітичними умовами XX століття. Цьому сприяли революційні рухи доби Української Держави та Української Народної Республіки, Друга 
світова війна, національно-визвольні змагання 30-50-х років. Псевдоніми використовувалися в радянському підпіллі та партизанському середовищі, були поширеними серед членів Організації Українських Націоналістів (ОУН) та вояків Української Повстанської Армії (УПА). Підпільники, бійці визвольних загонів не могли виступати під офіційними прізвищами: родини членів ОУН та УПА переслідували, тому вони змушені були приховувати свої прізвища та іменуватися псевдонімами.

У XXI столітті як окремий різновид псевдонімів розглядаємо «позивні», якими нині послуговуються учасники збройного російськоукраїнського конфлікту. Вони наділені інформативністю та високим характеристично-функційним потенціалом.

Натепер залишається актуальною проблема побудови повної тематичної класифікації псевдонімікону, що враховує динаміку сучасної соціокультурної комунікації в іï зіставленні 3 розвитком самоназивання в попередні періоди історії національної мови.

\section{1. Вивчення псевдонімів вітчизняними та іншими слов'янськими мовознавцями}

Українські псевдоніми висвітлені в працях О. Дея, В. Еппеля, П. Чучки, В. Німчука, М. Лесюка, О. Петрової, М. Торчинського, Н. Павликівської та інших. Вони порушили питання лінгвістичного статусу, призначення та функцій псевдоніма, структури класу псевдонімів, особливості псевдонімної номінації тощо.

В Україні ключем для розкриття псевдонімів, криптонімів письменників, журналістів, публіцистів, критиків та інших діячів культури стала відома праця О. Дея - «Словник українських псевдонімів та криптонімів (XVI-XX ст.)» (1969). Під час підготовки названого видання О. Дей використав усі джерела, що з'явились раніше. За свідченням автора, це «Словник псевдонімів українських письменників (матеріали)» О. Тулуба та «Матеріали до словника псевдонімів та криптонімів українських авторів» Б. Комарова, які 3'явилися у 20-х роках $\mathrm{XX}$ століття. У 20-30-х роках збиранням псевдонімів займалися Н. Кравченко-Максименко (бібліотекар Центральної наукової бібліотеки АН УРСР у м. Києві). Частину своїх надбань Н. Кравченко-Максименко передала I. Масанову, який використав їх під час укладання «Словаря псевдонимов», а частину Львівській науковій бібліотеці. У цих же роках (20-30-х) у Західній Україні принагідно збирав псевдоніми I. Калинович (збереглося близько 400 карток). Крім цього, картотеку діячів української журналістики, в основному ж галичан, уклали Зенон Кухля, Василь Винар (учитель із м. Бучача), але ці матеріали не віднайдено. Невелику 
картотеку псевдонімів зібрав західноукраїнський історик Мирон Кордуба, проте вона являла собою розписану на картки публікацію О. Тулуба.

У 30-х роках склав список на 1500 псевдонімів діячів української літератури й журналістики В. Дорошенко. У 1946 році переважно на матеріалах уже опублікованих словникових спроб Львівська наукова бібліотека у складі колективу з 4 осіб (Я. Дашкевича, К. Малицької, О. Суховерського та М. Штелінг) підготувала картотеку, в якій розшифровано близько 3500-4000 псевдонімів та криптонімів. На основі цієї картотеки було укладено і надруковано «Матеріали до словника псевдонімів українських письменників, учених та громадських діячів за 1800-1916 роки». До цього списку ввійшло 2500 псевдонімів, проте в ньому відсутні покликання на органи й книги, а також джерела, за якими вони розшифровуються. Псевдоніми публіцистів i письменників 20-30-х років збирав В. Півторадні, матеріали якого опубліковані в журналі «Архіви України» (1966, № 5, с. 100-107). Цим і обмежились спроби збирання та друкування матеріалів для українського словника псевдонімів ${ }^{1}$. Використані О. Деєм попередні джерела склали тільки частину матеріалу його словника. Багато псевдонімів розкривається в цій роботі на основі усної інформації, наданої укладачеві, велику кількість псевдонімів і криптонімів розшифровано на основі архівних документів. Словник розшифровує низку псевдонімів, що з'явилися в українських виданнях поза межами української етнічної території. До словника введено чимало псевдонімів діячів української культури, під якими вони виступали в російських, чеських, польських, німецьких, угорських, французьких та ін. виданнях.

Продовженням і доповненням «Словника» О. Дея стали «Нові матеріали до словника українських псевдонімів» (1999р.) В. Еппеля. Пропонована праця, за словами автора, $є$ лише невеликим кроком на шляху до створення нового Словника українських псевдонімів. Вона містить розкриття близько 1400 псевдонімів та криптонімів (до цього числа належать i деякі виправлення та уточнення до «Словника» О. Дея). Крім псевдонімів, записаних кирилицею, вміщено невеликий розділ псевдонімів латиною. До реєстру псевдонімів входять алоніми. Здебільшого укладач (на відміну від «Словника» О. Дея), крім справжнього імені та прізвища автора, подає ще й «основний» псевдонім, під яким автор нерідко $є$ більш знаним, аніж під справжнім прізвищем. До більшості псевдонімів та криптонімів, крім джерел їх

${ }^{1}$ Дей О.І. Словник українських псевдонімів та криптонімів (XVI-XX ст.). Київ : Наукова думка, 1969. С. 5-7. 
розкриття, подаються відомості про місця вживання цих псевдонімів: публікації в газетах, журналах, збірниках, у вигляді окремих книжок тощо. Здебільшого відомості про вживання псевдонімів мають лише приблизний характер.

Появу «Нових матеріалів» спричинило те, що за 30 років, які минули з часу видання Словника-1969, з'явилося багато нового, чимало нерозкритих або нерозібраних псевдонімів залишилося із попередніх десятиліть, особливо ж псевдоніми українських авторів, що живуть або жили поза Україною².

Важливе пояснення сутності псевдонімів знаходимо у статті П. Чучки «Українські псевдоніми: статус, структура і функції» (2001р.), у якій автор перераховує інтегральні ознаки українських псевдонімів, пропонує дефініцію поняття, визначає його ономастичний статус, розглядає структуру класу та внутрішню структуру самих псевдонімів, їх інформативність. На думку П. Чучки, у псевдонімів є достатня кількість інтегральних ознак, аби вважати їх онімами окремого класу в рамках національної антропосистеми. Таких визначальних ознак автор нараховує шість: 1) псевдонім, на відміну від антропонімів решти класів, - це самоназва (індивідуальна або групова), яку вибирає собі сам іменований; 2) псевдоніми є факультативними знаками, функціонування яких нинішнє законодавство не регламентує; 3) майже всі псевдоніми є неофіційними назвами (ті поодинокі, що вийшли на рівень загальнонаціональних, здебільшого конкурують зі справжніми прізвищами або 3 іменами їх носіїв; 4) псевдоніми не належать до спадкових іменувань, що зближує їх iз прізвиськами; 5) псевдонімів, зокрема літературно-художніх, у тієї самої особи може бути безліч; 6) майже кожен псевдонім є мотивованою, промовистою назвою, якою денотат не просто називає, але й характеризує себе $з$ позитивного боку. Ці ознаки, на нашу думку, є визначальними не для всіх розрядів псевдонімів, а тільки для літературно-мистецьких. Дослідження політичних псевдонімів дає нам змогу зауважити, що підпільники частіше отримували псевдоніми від своїх командирів чи побратимів по боротьбі, аніж прибирали їх самостійно. Псевдоніми підпільників однозначно не можна вважати самоназвами. Крім цього, вони не $є$ промовистими, оскільки це суперечить їхній конспіративній меті. Тому дефініція П. Чучки: «псевдоніми - це самоназви, які факультативно використовує творча особа поряд з їі справжнім прізвищем чи іменем 3 метою приховати своє авторське «я» або для маніфестації свого

2 Еппель В. Нові матеріали до словника українських псевдонімів. Київський національний університет будівництва і архітектури. Київ, 1999. С. 4. 
ідеологічного кредо» ${ }^{3}$, стосується передусім літературно-художніх псевдонімів.

Варто відзначити комплексний аналіз літературних i публіцистичних псевдонімів німецької та української мов, здійснений О. Петровою. Авторка здійснила зіставне дослідження принципів, способів і засобів псевдонімної номінації в зазначених мовах, виявила спільне й особливе у псевдонімії порівнюваних мов, розкрила національну специфіку творення самоназв. О. Петрова виявила спільні ознаки, які окреслюють режим функціонування псевдоніма як у німецькій, так і українській мові: 1) псевдонім існує паралельно зі справжнім іменуванням особи; 2) псевдонім $\epsilon$ самоназвою, яку присвоює собі автор; 3) використання псевдоніма пов'язане із суспільною, передусім творчою діяльністю його носія. Ці ознаки, зокрема дві останніх, прийнятні для псевдонімів літературних. Наводяться й інші ознаки псевдонімів, які розглядає авторка: псевдонім є факультативним антропонімом 3 обмеженою сферою вживання; він $є$ неофіційним, проте може вживатися в «офіційних» ситуаціях; псевдоніму притаманна інформативність, експресивність та оцінність; псевдонім виконує функцію умовної номінації реальної особи; псевдонім $\epsilon$ засобом самоідентифікації і позиціонування себе у суспільстві.

Те, що псевдонім $є$ факультативним антропонімом 3 обмеженою сферою вживання, що він $є$ неофіційним, що виконує функцію умовної номінації особи, притаманне псевдонімам усіх розрядів. Інші ж ознаки не $\epsilon$ абсолютними, далеко не всі псевдоніми позиціонують свого денотата у суспільстві.

Незаперечним є розгляд О. Петровою загальних мотиваційних типів (принципів) характеристичного виявлення псевдонімів: «людина в суспільстві», «людина i навколишній світ», «людина як така». Ці принципи номінації, на нашу думку, однаковою мірою чинні як у літературно-мистецькій, так і в суспільно-політичній псевдонімії. Чого не можна сказати про інші принципи найменування: відіменний, який грунтується на мотиваційному зв'язку псевдоніма зі справжнім ім'ям автора, та принцип латенції (називання, яке вказує на те, що справжнє iм'я автора приховане). Відіменний принцип i принцип латенції характерні більшою мірою для псевдонімів письменників, публіцистів. У політичній псевдонімії вони окреслені невеликою кількістю найменувань.

3 Чучка П.П. Українські псевдоніми: статус, структура і функції. Наукові записки Кіровоградського держ. педуніверситету ім. В. Винниченка. Серія: філол. науки (мовознавство). 2001. Вип. 37. С. 82. 
Дослідниками української політичної псевдонімії, зокрема членів Організації Українських Націоналістів та учасників Української Повстанської Армії, є М. Лесюк і В. Німчук.

Псевдоніми тих членів УПА, що воювали на теренах Прикарпаття, тобто колишньої Станіславської області, або були вихідцями 3 прикарпатських сіл, а також псевдоніми старшин УПА, провідних членів ОУН, членів УГВР, поданих П. Содолем, представлені М. Лесюком у статтях «Псевда вояків Української Повстанської Армії, 1999; «Неофіційний антропонімікон УПА», 2002. М. Лесюк акцентує увагу на таких важливих питаннях, як фактори, що відігравали роль у виборі і надаванні псевдоніма (освіта, походження, соціальний стан, родинні традиції тощо), семантична структура, шляхи виникнення та походження псевдонімів. Усі псевдоніми, що їх носили учасники УПА, дослідник поділяє на дві групи: 1) псевдоніми, що виникли від власних назв і 2) псевдоніми, що походять від апелятивів. До першої групи належать псевдоніми, що являють собою імена людей, прізвища (у вигляді звичайних прізвищ і прізвищ видатних історичних осіб, літературних героїв тощо), псевдоніми, утворені за етнічною належністю чи місцем проживання носіїв, псевдоніми, що відображають назви географічних об'єктів. Найчисленнішими у цій групі є псевдоніми, що являють собою імена людей. Основна ж маса партизанських псевдонімів - це відапелятивні назви, репрезентовані великою кількістю семантичних типів: назви зоофорного походження; назви фітофорного походження; назви професій; псевдоніми, перенесені від назв зброї; від назв мінералів; метеорологічних явищ; назви рельєфу; продуктів харчування; різних абстрактних понять; знарядь праці, витворів людських рук; музичних інструментів; родинних зв'язків; частин тіла людини тощо. Найчисленнішими із них $\epsilon$ псевдоніми, що віддзеркалюють флору Карпат, України і світу. Серед вторинних назв повстанців $M$. Лесюк розглядає псевдоніми композитної структури, а також велику групу особових назв прикметникової форми, які характеризують носія за певними ознаками (зовнішнім виглядом, кольором волосся, обличчя, очей, одягу; за внутрішніми рисами, вдачею, звичками, характером; за місцем походження, проживання; за фізичними властивостями; за розмірами; за віком; за соціальним станом, відношенням до колективу, родини).

Дослідник оунівської псевдонімії відзначає розмаїття псевдонімів та велику словоутворювальну фантазію повстанців. Він зазначає, що «у мовленні самих вояків УПА та членів підпільних організацій, у літературі про визвольні змагання уживається досить удалий «українізований» 
варіант цього терміна «псевдо» ${ }^{4}$. М. Лесюк належну увагу приділяє такому важливому питанню, як походження псевдонімів. Повстанські псевда, на його думку, поділяються на первинні та вторинні. У більшості наведені імена $€$ первинними, оскільки вони перенесені на денотата уже в готовому вигляді. Вторинними «можуть бути хіба що назви за походженням чи місцем проживання (Кубанець, Поділещь і под., тобто той, що приїхав з Кубані, Поділля); назви прикметникової форми (Місиевий, Польовий), псевда 3 неясною семантикою (Чарамандик, Шахай і под.); псевда у вигляді прізвищ, якщо мати на увазі, що синів Гордія, Корнія і под., використавши патронімічні суфікси, назвали Гордіснком, Корнієнком і под., як це мало місце в Україні у час творення офіційних прізвищ» 5 . Автор допускає, що мотивація надання (чи прийняття) цих псевдонімів могла бути й інша.

М. Лесюк, розглянувши псевдоніми членів УПА, що воювали на теренах Прикарпаття та оунівські псевдоніми, подані П. Содолем, пропонує таку дефініцію: «псевдонім - це неофіційна конотативна назва особи, яка відображає якусь певну ії характерну ознаку, несе інформаційне та емоційне навантаження і відома певному колу осіб» 6 . Запропонована дефініція $є$ досить повною і слушною, але, на нашу думку, не кожен псевдонім $\epsilon$ конотативною назвою особи. Так, скажімо, псевдоніми типу Тур, Сокіл, Джміль, Явір, Верба, Тополя, Картопля і под. та іншого походження не завжди наділені певною конотацією. Адже денотат може не відповідати за своїми особливостями найменуванню. Наприклад, псевдонім Дуб могла мати людина фізично здорова, кремезна або ж така, що зовсім не наділена відповідними якостями. Тому частина повстанських псевдонімів, за нашими спостереженнями, виконують лише номінативну функцію, без конотативних нашарувань.

Незаперечною $\epsilon$ думка М. Лесюка щодо лінгвістичного статусу псевдонімів: «партизанський антропонімікон - система і структура вторинних повстанських найменувань... Це цілий пласт української антропонімії...» ${ }^{7}$.

Важливі спостереження про псевдонімію оунівців зробив В. Німчук, обстеживши псевдонімікон ОУН-УПА збірника «Сколівщина», що побачив світ у 1996 році. Псевдонімія ОУН-УПА, за переконаннями дослідника, становить великий інтерес для лінгвістів, яким важливо

${ }^{4}$ Лесюк М.П. Псевда вояків Української Повстанської Армії. Studia Slawistyczne 1; Nazewnictwo na pograniczach etniczno - jezykowych. Białystok, 1999. C. 178.

${ }^{5}$ Там само. С. 184.

6 Лесюк М.П. Псевда вояків Української Повстанської Армії. Studia Slawistyczne 1; Nazewnictwo na pograniczach etniczno - jezykowych. Białystok, 1999. C. 179.

${ }^{7}$ Там само. С. $177-178$. 
досліджувати закономірності формування та функціонування такого специфічного розряду антропонімів - індивідуальних імен людей - на величезному фактичному матеріалі. В. Німчук слушно зауважує, що не всі псевдоніми $є$ самоназвами, а отже, характеристиками осіб із позитивного боку. У підпільних політичних організаціях псевдонімами стають не тільки самоназви, а й антропоніми, які тій чи іншій особі дають люди 3 іï оточення. Тут промовисті псевдоніми, зазначає автор, трапляються, але вони не бажані, бо за ними носіїв можуть пізнати і викрити. У підпіллі «Кучерявим» можуть назвати навіть лису людину, a «Велетом» людину середнього або невисокого зросту ${ }^{8}$.

На думку В. Німчука, основною причиною, що спонукає людину тимчасово або назавжди брати нове ім'я, $є$ прагнення особи уникнути відповідальності за свої вчинки та висловлені думки, конкретно бажання сховатися за псевдонім від переслідувачів, ворогів, властей (влади) і т. д. А виконує псевдонім свою функцію, поки він знаний вузькому колу довірених людей. Коли ж стає відомим непосвяченим у таємницю, то відповідна особа змушена прибирати нове ім'я.

У дослідженні $\mathrm{B}$. Німчука представлений широкий репертуар оунівських псевдонімів, похідних від власних назв і від апелятивів. Автор виокремлює низку тематичних груп: похідні від власних імен та прізвищ, зокрема від хресних імен носіїв, християнських імен або їх скорочень, здрібніло-пестливих варіантів, що звуковим складом нічим не нагадували справжне ім'я або прізвище їхніх носіїв; прізвищ (прізвиськ) діячів української історії, письменників, літературних героїв, інших прізвищ; псевдоніми-етноніми; назви людей за спорідненістю тощо. Дослідник політичної псевдонімії слушно зауважує, що псевдоніми вживалися і в радянському підпіллі та партизанському середовищі. I хоча в обстежених ним творах С. Ковпака, О. Федорова, П. Вернигори псевдонімів, окрім кількох прізвиськ, не було виявлено, проте у партизанському середовищі була набагато більше розвинена псевдонімія, ніж про це можна судити за спогадами учасників руху опору ${ }^{9}$.

Важливим для зіставлення $є$ дослідження польської партизанської псевдонімії С. Вархола "Nazewnictwo partyzanckie okregu Biała Rodlaska w latach 1939-1944”, 1987. Про спільні риси української псевдонімії i польської партизанської псевдонімії періоду Другої світової війни на теренах, прилеглих до українських етнічних територій, згадує В. Німчук. Багато спільного 3 польською партизанською псевдонімією

8 Німчук В.В. Про українську псевдонімію та криптонімію. Украӥнська мова. 2002. № 2. C. 31 .

${ }^{9}$ Там само. С. 35. 
знаходимо й у нашій розвідці оунівських псевдонімів. Передусім, це виявляється у способах та засобах псевдонімної номінації. У польській, як і в українській псевдонімії, основна маса партизанських псевдонімів - це назви, які виникли внаслідок семантичного переосмислення. Основними процесами були онімізація апелятивної та трансонімізація пропріальної лексики. За С. Вархолом, найвищу фрекленцію виявляють псевдоніми, які походять від апелятивів: їх використано 290 разів, що становить 55,7\% загальної кількості псевдонімів. Здебільшого це псевдоніми, які походять від назв тварин, на що ми акцентуємо увагу і в нашому дослідженні. Серед відапелятивних похідних С. Вархол розглядає назви рослин; назви за професією та родом занять; метеорологічні назви; назви зброї; назви гірських порід, мінералів, назви топографічних об'єктів; назви на позначення абстрактних понять та ін. С. Вархол виявив 230 псевдонімів, які походять від власних назв, що становить 44\% від загальної кількості. Серед них найчисленнішими виявилися відантропонімні похідні, зокрема від імен і прізвищ. Похідні від інших власних назв (етнічних, географічних) утворюють кількісно менші групи. У польській партизанській псевдонімії, як і в українській оунівській, популярним було у ролі псевдонімів використовувати імена історичних діячів, літературних героїв.

Отже, українська і польська партизанська псевдонімія позначена багатьма спільними рисами, грунтується загалом на всеслов'янській літературно-мовній основі. Однак простежуються національні особливості, зокрема в лексемах, підданих псевдонімізації.

Детальне структурування антропонімного простору української мови загалом і псевдонімів зокрема 3 позицій співвідношення власних особових назв 3 їхніми денотатами зробив М. Торчинський («Денотатно-номінативна структура антропонімікону української мови», 2007). Автор цієї розвідки структурував псевдоніми відповідно до їх носіїв: політик-псевдоніми, міліті-псевдоніми, логос-псевдоніми, спорт-псевдоніми, клерикал-псевдоніми тощо ${ }^{10}$.

Об'єктом дослідження Н. Павликівської стали українські псевдоніми (літературно-мистецькі, громадсько-політичні, кримінальні) та криптоніми XX століття. У 2009 році було підготовлено монографію «Питання українськоїпсевдонімії XX століття», у якій уперше здійснено комплексне вивчення i зіставне дослідження українських літературно-мистецьких, громадсько-політичних та кримінальних псевдонімів XX століття, аналіз яких дав змогу глибше пізнати своєрідність їх системної організації,

10 Торчинський М.M. Денотатно-номінативна структура антропонімікону української мови. Наукові праці Кам'янець-Подільського держ. ун-ту: Філологічні науки. Випуск 15. Т. 1. Кам'янець-Подільський : Аксіома, 2007. С. 148-149. 
3'ясувати особливості формування i функціювання псевдонімів як окремого сектору ономастичного простору. Автором цієї студії розв'язано низку питань: вивчено і розкрито специфіку псевдоніма 3 погляду його лінгвістичного статусу, структури, функціональних можливостей; визначено лінгвомотивацію лексем, підданих псевдонімізації, основні принципи, мотиви, способи та засоби номінації в українській псевдонімії; 3'ясовано функціональне навантаження та «об'єм» основної та додаткових функцій псевдонімів різних соціально-професійних груп; досліджено структурно-словотвірні типи псевдонімів; вивчено екстралінгвальні чинники, що детермінують процес їх становлення; здійснено порівняльний аналіз формування й функціонування літературних, політичних й інших псевдоантропонімів; укладено бібліографічний покажчик.

Здійснене дослідження дало змогу умотивувати власне розуміння псевдоніма як особливого різновиду антропоніма і запропонувати

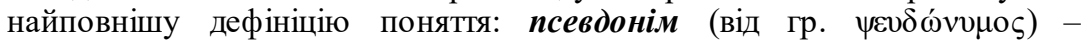
різновид антропоніма, прибране (вигадане) особове іменування, яке використовують представники окремих груп суспільства (письменники, публіцисти, композитори, актори, художники, співаки, громадськополітичні діячі, злочинні елементи) поряд зі своїм справжнім іменем та прізвищем або замість них 3 метою конспірації через причини особистісного, політичного та юридичного характеру.

У разі виділення інтегральних ознак псевдоніма необхідно враховувати лінгвістичний статус цієї номінації, сферу, тривалість вживання, оскільки різні класи псевдонімів мають свої особливості. Виділяємо такі визначальні ознаки псевдоніма:

1) ознаки лексичної семантики: а) вторинна назва особи; б) факультативна назва, нерегламентована законодавством; в) назва здебільшого позначена інформативністю та характеристичністю; г) назва, що залежно від сфери вживання може набувати певних конотацій та виконувати у зв'язку з цим додаткові функції (оцінну, символічну, естетичну та ін.);

2) соціокомунікативні та функціональні ознаки: а) неофіційна назва людини, але може вживатися в офіційних ситуаціях; б) псевдонім має особливе призначення - оберігати таємницю справжнього іменування носія; в) псевдонім виконує особливу функцію - езотеричну, яка не властива іншим антропонімам; г) використання псевдоніма пов'язане із суспільною діяльністю носія (письменники, журналісти, актори та ін.; громадсько-політичні діячі, підпільники, злочинні елементи); г) псевдоніми можуть бути самоназвами (літературно-мистецькі) або надаватися 3 боку оточення (більшість громадсько-політичних, кримінальних); д) функціональне навантаження псевдоніма залежить від належності його до певного класу: так, літературно-мистецькі 
самоназви можуть набувати сталості й заступати справжнє ім'я людини, стаючи знаковим елементом історії культури, прецедентним феноменом, для інших же характерне вживання лише протягом певного періоду - доти, доки ним послуговується сам носій; е) псевдонім, який стає єдиним іменем людини, втрачає свою специфіку і переходить в інший антропонімічний розряд; є) псевдоніми не успадковуються; ж) особа може мати один, кілька й багато псевдонімів.

На увагу заслуговує й подальше вивчення української псевдонімії. Псевдонімікон XXI століття розкриє нові віхи вторинної номінації осіб, особливості номінаційних процесів, семантичні, соціокомунікативні та функціональні ознаки пропріативів.

\section{2. Специфіка та функційні ознаки псевдоніма як особливого різновиду антропоніма}

Специфіка псевдоніма полягає насамперед у його особливому призначенні. Серед загальної маси власних імен псевдонім вирізняється за такими ознаками: 1) це антропонім, який виконує езотеричну функцію, яка відсутня в інших антропонімів; 2) це антропонім вторинної номінації; 3) він необов'язковий, а факультативний, з обмеженою сферою вживання; 4) антропонім - самоіменування, створений або відібраний самим носієм; 5) на відміну від літературних антропонімів, він $€$ антропонімом реальним ${ }^{11}$. Псевдоніми не належать до спадкових іменувань; псевдонімів, зокрема літературно-художніх, у тієї самої особи може бути безліч; майже кожен псевдонім $\epsilon$ мотивованою, промовистою назвою, яка характеризує денотата 3 позитивного боку ${ }^{12}$.

Дослідження на широкому матеріалі дає змогу внести деякі корективи до окремихвизначень, зокрема, що псевдонім - це не тільки самоназва, а й найменування, яке денотат отримує від колективу, близького оточення. I що у політичній псевдонімії, зокрема членів ОУН і учасників УПА, промовисті псевдоніми не бажані, бо за ними носіїв можуть пізнати i викрити $^{13}$. Здійснене нами дослідження української псевдонімії XX століття, літературно-мистецької та громадсько-політичної загалом дає змогу погодитися $з$ вищеназваними ознаками псевдоніма як особливого різновиду антропоніма. Однак необхідно враховувати, що псевдоніми

11 Суркова Т.И. Псевдонимы как особый тип антропонимов. Русская ономастика. Рязань : Рязанский гос. пед. ин-т, 1977. С. 97.

12 Чучка П.П. Українські псевдоніми: статус, структура і функції. Наукові записки Кіровоградського держ. педуніверситету ім. В. Винниченка. Серія: філол. науки (мовознавство). 2001. Вип. 37. С. 82.

13 Німчук В.В. Про українську псевдонімію та криптонімію. Украӥнська мова. 2002. № 2. C. 31. 
різняться між собою за сферою вживання (літературні, мистецькі, партизанські й ін.). 3 огляду на це основними ознаками псевдоніма вважаємо: 1) його особливе призначення - охороняти таємницю справжнього імені; 2) псевдоніми $є$ вторинними, факультативними назвами, які існують паралельно зі справжнім іменем або замість нього; 3) псевдоніми можуть бути як самоназвами, так і надаватися з боку колективу, оточення; 4) псевдоніми наділені значним інформативним потенціалом; 5) псевдоніми багатофункціональні, залежно від сфери вживання, крім основної, можуть виконувати й інші функції: характеристичну, естетичну, оцінну, символічну; 6) одна і та сама людина може мати один, кілька і багато псевдонімів; 7) псевдоніми можуть бути промовисті (літературно-художні) i, навпаки, створені за принципом антитези (політичні).

Як і кожна власна назва, псевдонім виконує номінативну функцію. Проте у псевдонімії номінація має особливий езотеричний характер (пор. езотеричний - той, що містить внутрішній, глибинний або таємний, прихований сенс; прот. екзотеричний. ** Езотеричне знання таємне вчення, відоме лише вузькому колу обраних осіб - ВТС, c. 255) - співвідношення імені і номінатора відоме лише посвяченим у таємницю, вузькому колу людей.

Авторка вважає, що у політичних псевдонімів на першому місці виступає езотерична функція, але присутніми в них можуть бути емоційно-естетична і соціально-характеристична функції. У сценічних псевдонімах на перше місце висувається естетична функція. Суттєвою особливістю літературних псевдонімів $є$ складна взаємодія функцій, більший ї набір щодо інших типів псевдонімів. В них основну функцію доповнюють інші функції: характеристична, емоційна, символічна, комічна, функція стилізації.

Отже, «об'єм» основної функції у різних типів псевдонімів неоднаковий. У політичній псевдонімії езотерична функція $\epsilon$ домінуючою, інші псевдоніми, як правило, поліфункціональні.

Псевдонім, зокрема політичний, виконує свою функцію, поки він знаний вузькому колу довірених людей. Псевдоніми, будучи поліфункціональними, виражають думки, настрій своїх носіїв, беруть участь у популяризації їх творчого задуму, визначають їхне світобачення тощо. Щодо інформативності українських псевдонімів, то iï ступінь дуже високий, і тому псевдоніми заслуговують значно більше уваги $з$ боку мовознавців та літературознавців, ніж це було дотепер ${ }^{14}$.

14 Чучка П.П. Українські псевдоніми: статус, структура і функції. Наукові записки Кіровоградського держ. педуніверситету ім. В. Винниченка. Серія: філол. науки (мовознавство). 2001. Вип. 37. С. 82. 
Ми погоджуємося 3 думками дослідників щодо інформативності та функціонального навантаження псевдонімів. Виходячи 3 наших досліджень літературно-мистецької та політичної псевдонімії, вважаємо, що основною функцією будь-якого псевдоніма після номінативної $\epsilon$ езотерична, оскільки його призначенням $\epsilon$ «приховати» справжнє ім'я автора. Проте залежно від сфери функціонування псевдоніми мають різний «об’єм» цієїфункції. У псевдонімії учасників козацько -селянського революційного руху доби Української Держави та Української Народної Республіки, учасників національно-визвольних змагань (ОУН-УПА), радянських підпільників, розвідників, партизанів езотерична функція $€$ домінуючою, хоча на неї нерідко нашаровуються й додаткові функції.

У псевдонімії діячів культури - письменників, журналістів, акторів, музикантів, співаків, художників й ін., спостерігаємо поліфункціональність, тобто основна функція обов'язково взаємодіє 3 іншими функціями. У багатьох псевдонімах діячів культури на перше місце висуваються додаткові функції, у результаті чого творча особа самоназву використовує для маніфестації свого ідеологічного кредо.

Серед додаткових функцій як у літературній, так і в політичній псевдонімії репрезентативними $є$ характеристична, оцінна, експресивна та символічна функції.

Характеристична функція яскраво проявляється у псевдонімах, похідних від номенів на позначення діячів за професією, постійним або тимчасовим заняттям, функціями, посадами. Діячі культури прибирали переважно такі псевдоніми, як: Літератор, Імпресіоніст, Літописеиь, Байкар, Критик, Рецензент, Театрал, Гімназист, Студент, Педагог, Професор та ін. Підпільників, зокрема членів ОУН і воїнів УПА, псевдоніми характеризували як представників сільськогосподарських та робітничих професій: Сівач, Хлібороб, Рибак, Пасічник, Кравещь, Тесля, Ткач, Чабан та ін.

Характеристичними $є$ псевдоніми, сформовані від назв осіб за становищем у суспільстві: Бурлака, Сірома, Волоиюга, Бродяга, Ватажок, Панич, Скиталець, Шляхтич та ін.; від етнонімів: Украйнець, Гуиул, Верховинеиь, Грек, Ляшок, Черкес, Подоляк, Бойко та ін.; від номенів на позначення зовнішності, вікових особливостей людини: Кучерявий, Лисий, Щербатий, Сорокатий, Чорнобривий, Русявий, Сивий, Вусатий, Горбатий, Старий, Малолітній і под.

Характеризують своїх носіїв псевдоніми, перенесені від назв предметів, зброї, знарядь праці, витворів людських рук тощо: Шиилька, Шиччка, Довбня, Бомба, Стріла, Сокира і под.

Оцінна функція притаманна переважно псевдонімам прикметникового походження: Дика, Вільний, Спостережливий, Дивний, Об'єктивний, Скромний, Благий, Недолугий, Шпетний (діал. 
поганий, бридкий); похідні від атрибутивних назв осіб: Негідник, Бережко, Гуляка, Забіяка, Доброволець, Вередун, Причепа та ін.

Експресивна функція проявляється у псевдонімах, сформованих від субстантивованих прикметників: Лагідний, Ласкавий, Тихий, Ярий, Сумний, Веселий, Грізний, Лютий, Ясний і под.; від назв топографічних об'єктів: Вир, Хвиля, Прірва, Вершина, Пік та ін.; від назв на позначення гірських порід: Скеля, Кремінь, Криия та ін.; від назв на позначення світлових та звукових явищ природи: Іскра, Грякіт, Свист, Шум тощо.

Варто зазначити, що більшість псевдонімів поліфункціональні. На основну функцію можуть накладатися одночасно і характеристична, і оцінна, і експресивна.

Серед додаткових функцій псевдоніма особливе місце займає символічна функція. До складу таких псевдонімів входить лексика, що має виразні національні конотації. Це, передусім, опоетизовані рослини, тварини, фольклорні образи: Горлиия, Ластівка, Лебедик, Соколик, Калина, Рута, Барвінок та ін.

Рідше псевдоніми наділені функціями самоіронії та стилізації, зокрема у діячів культури: Фріи Мазня, Бовдур, Дід Василь недобитий, фельдшер геодрапічних наук, Параска з-під солом'яної стріхи, Старенька Муха, Зоотехнік історичних наук, дід Перебендя, Хлоп зміста та ін. Найменування такого типу у політичній псевдонімії трапляються вкрай рідко: Панько Хрін, Панько Торба .

Псевдоніми, будучи поліфункціональними, не тільки «маскують» свого носія, а й увиразнюють фізичні, психічні, інтелектуальні якості людини, показують iii світобачення, передають національний колорит, обрядову символіку тощо.

Важливим питанням у разі розгляду номінаційних особливостей псевдоніма $\epsilon$ питання про вибір номінативних форм. Цей вибір зумовлений як загальними закономірностями виникнення лексичних одиниць, так і специфікою засобів вторинного називання. У ролі псевдоніма використовуються готові слова або створюються нові.

Використання готових лексичних одиниць для позначення денотата характеризується широким застосуванням антропонімів (прізвищ, імен, імен по батькові), топонімів (гідронімів, ойконімів, оронімів), міфонімів, астронімів та апелятивів. Псевдоніми формуються шляхом онімізації апелятивної та трансонімізації пропріальної лексики. Такий спосіб номінації високопродуктивний як у літературно-мистецькій, так i в політичній псевдонімії. Продуктивним було використання антропонімів, особливо прізвищ та імен, апелятивної лексики. Рідше за псевдоніми правили топоніми, міфоніми і зовсім рідко астроніми. 
Псевдоніми, сформовані шляхом перенесення готової лексеми на людину, мають форму іменників, прикметників, рідше дієслівних форм, займенників, числівників, вигуків (Дуб, Шпилько, Лютий, Лисий, Рубай, Хтось, Сам, Один, Троє, Тук, Стоп).

Творення псевдонімів способом деривації широко практикувалося у літературно-мистецькій псевдонімії. Це афіксація довільно обраних загальних чи власних назв, афіксація справжнього іменування автора, штучна деформація справжнього іменування та субституція його окремих елементів (Дніпровський П. - Сліпчук Петро; Хвилинський Георгій - Хоткевич Гнат; Василенко Петро - Одарченко Петро Васильович; Юрченко Юр. - Яновський Юрій; Чивомискам Максимович Михайло; Химко Андрій - Хименко Андрій; Вроцький Н.А. - Навроцький Олександр; Волошка Іван - Волошин Іван; Лан Павла - Талан Павлина; Циганенко - Циганко П.В.).

У літературній псевдонімії популярністю користувалися префіксальні утворення 3 афіксом-часткою не- (Не літератор; Не родич; Не дипломат; Не лікар; Не поет; Не-січовий Стрілеиь, НеШевченко, Не-Перебендя).

У політичній псевдонімії спосіб деривації менш продуктивний. Творення псевдонімів способом деривації включає переважно афіксацію довільно обраних загальних чи власних назв (Вознесенко, Очеретенко, Бистрик, Зорич, Бродій, Горилов, Соловеиький). Зрідка трапляються похідні від особового імені батька денотата (Мусієнко Гаврилюк Михайло Мусійович); деякі псевдоніми утворилися шляхом приєднання афікса до особового імені денотата 3 метою перетворення його на прізвище (Іванчук - Вересюк Іван; Осипенко - Дяків Осип); окремі утворені шляхом видозміни справжнього іменування носія (Корчак - Корчинський Іван; Поль - Польовий Федір; Заєиъ Заячківський). Зафіксовано невелику кількість префіксальних та префіксально-суфіксальних утворень (Підполудний, Піддубний, Заріжний, Наколісний).

Українські псевдоніми XX століття сформовані і в результаті дії специфічного способу номінації, який грунтується на модифікації справжнього іменування автора. У літературно-мистецькій псевдонімії цей спосіб більш продуктивний. Модифікація справжнього іменування діячів культури репрезентована використанням замість повного іменування лише особового імені, його гіпокористичної чи демінутивної форми; зміною особового імені чи імен у разі збереження прізвища (Ногін Панас - Ногін Петро); розширенням офіційного іменування за рахунок додавання до прізвища певного елемента (Матушевський-Сфремов - Сфремов Сергій). 
У політичній псевдонімії модифікація справжнього іменування носія представлена використанням у ролі псевдоніма його особового імені, частіше його варіантної форми (Юрко - Середницький Юрій; Ванька - Іван Юрченко; Петя - Якімов Петро).

Варто зазначити, що політичні псевдоніми на противагу літературним у більшості однослівні, двослівні трапляються рідко (Друг Псельський - Осьмак Кирило; Панько Хрін, Панько Торба Степан Стебельський). Деякі псевдоніми скомпоновані за моделлю повного іменування людини (Коваль Іван Пилипович - Осьмак Кирило Іванович).

Крім псевдонімів-слів, як засоби вторинної номінації використовувалися астериски (зірочки), ініціали, цифри. Загальна назва зашифрованих підписів - криптоніми (від грец. kryptos - «таємничий»). Криптонімами широко користувалися діячі культури, особливо письменники. Проте вони не були популярними у підпільників. Це пояснюється тим, що криптоніми незручні для живого мовного спілкування.

\section{ВИСНОВКИ}

Отже, на основі аналізу лінгвістичних досліджень антропонімної категорії псевдоніма з'ясовано, що українські псевдоніми є окремим видом антропонімів. Псевдоніми нагадують прізвища й особові імена, зв'язок 3 якими простежується у використанні для створення псевдонімних форм їх структурно-словотвірних моделей. У значенні простежується близькість між псевдонімами, прізвиськами і кличками. Нерідко прізвиська та клички, використані 3 метою конспірації, виступають синонімами псевдонімів.

Псевдонім $є$ насамперед факультативним антропонімом i використовується представниками певних соціально-професіональних груп: письменниками, журналістами, художниками, композиторами, акторами, співаками, політиками, підпільниками, злочинними елементами поряд з їхнім справжнім прізвищем чи іменем або замість нього.

Особливість псевдоніма як засобу вторинної номінації особи полягає у його призначенні. Псевдонім існує до того часу, доки знаний вузькому колу людей. Тому особливою функцією псевдоніма вважаємо езотеричну. Найвищий ступінь «псевдонімності» мають політичні псевдоніми. Для літературних i мистецьких псевдонімів це було важливим лише на початку XX століття. У другій половині XX століття потреба «ховатися» зникла, тому псевдоніми використовувалися діячами культури 3 метою самоідентифікації, маніфестації свого ідеологічного кредо, ідеї творчості. 
Крім основної функції (номінативної), псевдоніми можуть виконувати додаткові функції: характеристичну, оцінну, експресивну, символічну, функцію вираження самоіронії. Нашарування додаткових функцій на основну властиве насамперед літературно-мистецьким псевдонімам.

Псевдонім може бути самоназвою або надаватися людині з боку оточення (політичні, кримінальні). Літературно-мистецькі псевдоніми це самоназви, більшість 3 яких презентують автора 3 позитивного боку.

Псевдоніми посідають важливе місце в системі власних назв людей. Вони мають низку спільних і відмінних рис 3 іншими антропонімами. Спільність псевдоніма 3 іменами, прізвищами, іменами по батькові виявляється у використанні для його створення їхніх моделей. А подібно до прізвиськ, псевдоніми - це вторинні, факультативні назви, наділені вагомим характеристичним потенціалом.

Отже, псевдоніми - це великий пласт української пропріальної лексики, який претендує на глибоке і різнобічне наукове вивчення.

\section{АНОТАЦІЯ}

У статті йдеться про псевдоніми як засоби вторинної номінації особи. Зазначено, що псевдоніми $є$ мовною універсалією і зміст поняття «псевдонім» сформувався ще в античному світі. Розглядаються екстралінгвальні чинники псевдонімності представників окремих груп суспільства. Подається історія вивчення псевдонімів вітчизняними мовознавцями, які порушували питання лінгвістичного статусу, призначення та функцій псевдоніма, особливості псевдонімної номінації тощо. Наголошується на тому, що специфіка псевдонімної номінації полягає у свідомому виборі мотиву іменування. Українській псевдонімії притаманний значний ступінь інформативності.

Українська псевдонімія як великий пласт пропріальної лексики претендує на подальше вивчення іiі семантико-мотиваційної бази та структури, екстралінгвальних чинників появи такого різновиду номінацій особи, причин презедентності в цьому номінаційному класі слів.

\section{ЛІТЕРАТУРА}

1. Дей О.І. Словник українських псевдонімів та криптонімів (XVIXX ст.). Київ : Наукова думка, 1969. 559 с.

2. Еппель В. Нові матеріали до словника українських псевдонімів. Київський національний університет будівництва і архітектури. Київ, 1999. 116 c. 
3. Лесюк М.П. Псевда вояків Української Повстанської Армії. Studia Slawistyczne 1; Nazewnictwo na pograniczach etniczno jezykowych. Białystok, 1999. C. 117-184.

4. Німчук В.В. Про українську псевдонімію та криптонімію. Украӥнська мова. 2002. № 2. С. 30-58.

5. Суркова Т.И. Псевдонимы как особый тип антропонимов. Русская ономастика. Рязань : Рязанский гос. пед. ин-т, 1977. С. 91-100.

6. Торчинський М.M. Денотатно-номінативна структура антропонімікону української мови. Наукові праці Кам'янещьПодільського держ. ун-ту: Філологічні науки. Випуск 15. Т. 1. Кам'янець-Подільський : Аксіома, 2007. С. 146-150.

7. Чучка П.П. Українські псевдоніми: статус, структура і функції. Наукові записки Кіровоградського держ. педуніверситету ім. В. Винниченка. Серія: філол. науки (мовознавство). 2001. Вип. 37. C. $82-83$.

Information about the authors: Pavlykiuska N. M., Doctor of Philological Science, Professor, Vinnytsia Mykhailo Kotsiubynskyi State Pedagogical University 32, Ostrozhskogo str., Vinnytsia, 21001, Ukraine

Prokopchuk L. V., Candidate of Philological Science, Associate Professor, Vinnytsia Mykhailo Kotsiubynskyi State Pedagogical University 32, Ostrozhskogo str., Vinnytsia, 21001, Ukraine 